慶應義塾大学学術情報リポジトリ

Keio Associated Repository of Academic resouces

\begin{tabular}{|c|l|}
\hline Title & Mutagenicity of a-hydroxy N-nitrosamines in V79 Chinese hamster cells \\
\hline Sub Title & \\
\hline Author & 望月, 正隆(Mochizuki, Masataka) \\
& $\begin{array}{c}\text { 長部, まり( Osabe, Mariko) } \\
\text { 安生, 孝子( Anjo, Takako) } \\
\text { 武田, 啓( Takeda, Kei) } \\
\\
\text { 鈴木, 恵真子( Suzuki, Emako) } \\
\text { 岡田, 正志( Okada, Masashi) }\end{array}$ \\
\hline Publisher & 共立薬科大学 \\
\hline Publication year & 1984 \\
\hline Jtitle & 共立薬科大学研究年報 (The annual report of the Kyoritsu College of \\
& Pharmacy). No.29 (1984.),p.100- 101 \\
\hline JaLC DOI & \\
\hline Abstract & \\
\hline Notes & 学会講演要旨 \\
\hline Genre & Technical Report \\
\hline URL & https://koara.lib.keio.ac.jp/xoonips/modules/xoonips/detail.php?koara_id=AN00062898-0000002 \\
\hline
\end{tabular}

慶應義塾大学学術情報リポジトリ(KOARA)に掲載されているコンテンツの著作権は、それぞれの著作者、学会または出版社/発行者に帰属し、その権利は著作権法によって 保護されています。引用にあたっては、著作権法を遵守してご利用ください。

The copyrights of content available on the KeiO Associated Repository of Academic resources (KOARA) belong to the respective authors, academic societies, or publishers/issuers, and these rights are protected by the Japanese Copyright Act. When quoting the content, please follow the Japanese copyright act. 


\title{
含水溶媒中のアミノ酸を過塩素酸で電位差滴定するときの 溶媒の影㗽について
}

\author{
小出裕子, 竹内洋子, 土谷美智子, 鹿島 哲, 河村倫子 \\ [日本薬学会 第 104 年会（1984年 3 月，仙台）で発表]
}

〔目的〕 アミノ酸を含水溶媒を使って $\mathrm{HClO}_{4}$ 水溶液で滴定するとさ, 有機溶媒の種類及び水 との混合比が滴定に及ぼす影響, 並びにその応用について検討する。

〔方法】 $0.02 \mathrm{~mol} / \mathrm{kg}$ アミノ酸試料溶液 $50 \mathrm{~g}$ を重量ビュレットで秤取し,メトローム社製タ イトロプロセッサーにガラス電極及び $3 \mathrm{~m} \mathrm{LiCl} 50 \%$ エタノール溶液を用いた銀・塩化銀電極を 接続し, $25.0^{\circ} \mathrm{C}$ で窒素ガスを導入し一定速度で筧拌しながら $1 M \mathrm{HClO}_{4}$ 標準液で滴定 記 録し た。溶媒にはメタノール，エタノール，2-プロパノール，アセトン及び 1,4-ジオキサンを用い， 水/有機溶媒のモル比を $16 / 1,8 / 1,4 / 1$ および $2 / 1$ などと変えて行った。滴定曲線の形, $1 / 2$ 当 量点と $3 / 2$ 当量点の電位とその差などから, 溶媒の比誘電率, 酸塩基性, 自己プロトン解離定数 及びアミノ酸双極イオンに対する溶媒和が滴定に及ぼす影響について検討する。

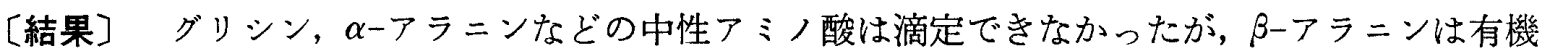
溶媒の含量比を高くすることによって, その塩基性を強め, 溶媒の酸性領域が拡大するため, 滴 定可能になり含水ジオキサンが良い結果を示した。

塩基性アミノ酸のアルギニン及びヒスチジンでは, 有機溶媒の含量が増加するにつれ, 双極イ オンの割合が減少し, 中性分子型が増加するので，その塩基性は弱まり，2 価の塩基のため, 電 位の変化が減少していった。

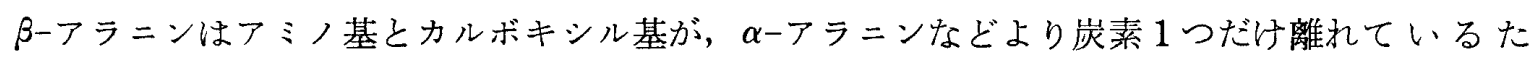
め, 塩基性がやや強く表われたと考光られる。

\section{Mutagenicity of $a$-Hydroxy $\mathrm{N}$-Nitrosamines In V 79 Chinese Hamster Cells}

\author{
望月正隆, 長部まり子*, 安生孝子*, 武田 啓*, \\ 鈴木恵真子*, 岡田正志*
}

[8th International Meeting on N-Nitroso Compounds (Banff, Canada, September, 1983) で発表]

$N$-Nitrosodialkylamines are metabolically activated through $\alpha$-hydroxylation. Chemical properties and bacterial mutagenicity of $\alpha$-hydroxy $N$-nitrosamines have been reported previously. This paper described a potent and direct mutagenicity of four $N$-nitroso- $N$ (hydroxymethyl)alkylamines (alkyl=methyl, ethyl, propyl, and butyl) in V79 Chinese hamster cells using ouabain resistance as an indicator. The mutagenic potency depended on the alkyl group, decreasing in the following order: methyl>ethyl>propyl, butyl. 
A similar order was observed also in the cytotoxicity. Mutagenic and cytotoxic potencies of these $\alpha$-hydroxy $N$-nitrosamines in V79 cells were well correlated not only with those of model compounds, $\alpha$-acetoxy and $\alpha$-hydroperoxy $N$-nitrosamines, but with their alkylating ability measured by alkylation of thiophenol. The mutagenic activity of the $\alpha$-hydroxy $N$-nitrosamines in V79 cells was shown to be in parallel with that in Salmonella typhimurium TA1535 and with that of $N$-nitrosodialkylamines in V79 cells after metabolic activation by rat hepatocytes. The results obtained here supported further that the $\alpha$-hydroxy $N$-nitrosamine is the active species in the metabolic activation of carcinogenic and mutagenic $N$-nitrosodialkylamines.

* 東京生化学研究所

\title{
Metabolism of $\mathbf{N}$-Nitrodialkylamines
}

\author{
鈴木恵真子*, 望月正隆, 関口奈保子, 岡田正志*
}

[8th International Meeting on N-Nitroso Compounds (Banff, Canada, September, 1983) で発表]

In vitro and in vivo metabolism of $N$-nitramines were investigated to compare their mode of action with that of $N$-nitrosamines. $N$-Nitrodibutylamine and $N$-nitrodiethylamine were incubated with rat liver microsomes and hepatocytes, and the products were analyzed by HPLC and GLC. The in vitro metabolic pattern of these $N$-nitramines was quite similar to that of the corresponding $N$-nitrosamines except that $N$-nitromonoalkylamines (produced by $\boldsymbol{a}$-hydroxylation) were isolated and characterized in the incubation with the $N$-nitrodialkylamines. Seven $N$-nitramines including glucuronides were isolated and identified from urine of rats given $N$-nitrodibutylamine, which were produced by $\omega, \omega-1$, and $\alpha$ oxidations of the $N$-nitramine. The in vivo metabolic pattern of $N$-nitrodibutylamine was also similar to that of $N$-nitrosodibutylamine, except that $N$-nitromonobutylamine (a product of $\alpha$-hydroxylation) was isolated and characterized.

$N$-Nitramines were mutagenic to $E$. coli WP2 $h r^{-}$but not to S. typhimurium TA1535. $N$-Nitrodibutylamine and $N$-nitrodiethylamine were mutagenic only in the presence of hepatic microsomes, while $N$-nitromonobutylamine and $N$-nitromonoethylamine were direct mutagens. Thus, the $N$-nitrodialkylamine is also metabolically activated to a mutagen through $\alpha$-hydroxylation.

* 東京生化学研究所 